\title{
Acute Undifferentiated Human Diarrhea in the Tropics
}

\section{ALTERATIONS IN INTESTINAL MICROFLORA}

\author{
S. L. Gorbach, J. G. Banwell, B. D. Chatterjee, B. Jacobs, and \\ R. B. SACK \\ From the Johns Hopkins University Center for Medical Research and Training, \\ School of Tropical Medicine, Infectious Diseases Hospital, Calcutta, India, \\ and Department of Medicine, University of Illinois College of Medicine, \\ Chicago, Illinois 60680
}

\begin{abstract}
A B S TRACT The microflora of the small and large intestine was determined in 17 adults with acute undifferentiated diarrhea in Calcutta, India. On the basis of bacteriologic findings, the patients could be divided into two groups: those with a predominant flora of Escherichia coli (eight patients) and those with a mixed coliform flora (nine patients). In the former group, E. coli were distributed throughout the small and large bowel. Broth filtrates of these isolates contained an enterotoxin which caused fluid accumulation in the rabbit intestinal loop model. Toxigenic $E$. coli were cleared rapidly from the small bowel during the acute period; some patients only had the "hot" strains in their fecal effluent. During convalescence, the serotypes of $E$. coli changed and the new strains did not elaborate enterotoxin. Only one of the eight patients had a serotype previously associated with diarrhea. Acute undifferentiated diarrhea in the remaining cases was apparently caused by untypable $E$. coli or by typable strains not generally considered pathogenic.

Small bowel and fecal cultures from the mixed flora group revealed a heterogeneous mixture of Gram-negative enteric bacilli and a distinct pattern could not be discerned. Further study will be needed to elucidate the cause of diarrhea in these cases:
\end{abstract}

\section{INTRODUCTION}

Acute diarrheal disease is a major cause of morbidity and mortality of adults residing in the tropic. Although clinical and epidemiological data suggest an infectious etiology (1), pathogenic microorganisms cannot be iso-

Dr. Gorbach's present address is Box 91, Cook County Hospital, Chicago, IIl.

Received for publication 22 April 1970 and in revised form 4 November 1970. -lated in $50-80 \%$ of acute cases (2-5). This lack of microbiological diagnosis has led to the euphemistic terms "nonspecific gastroenteritis" and "acute undifferentiated diarrhea" (AUD). ${ }^{1}$

Our approach to acute diarrheal disease in Calcutta, India, was to examine quantitative aspects of the intestinal microflora based on guidelines previously established in cholera diarrhea. In cholera, the invading pathogen colonizes the entire gastrointestinal tract, from the mouth to the anus $(6,7)$.Vibrio cholerae elaborates an enterotoxin which alters the physiology of the bowel mucosa causing net secretion of water and electrolytes (8). Similar alterations were looked for in patients with AUD by combining marker perfusion studies with intubation for bacteriology. Pathophysiological events were examined at the site of bacterial colonization of the small bowel during the acute and early convalescent periods; the results of the physiological studies are reported in the accompanying paper (9). Strains of bacteria designated as possible pathogens by bacteriological and marker perfusion studies were further studied in the isolated rabbit intestinal loop model. Cell-free, broth filtrates of E. coli isolated from diarrheal cases produced dilatation and fluid accumulation in the intestinal loop. These changes were similar to those induced by filtrates of Vibrio cholerae.

The purpose of these studies was to search for new pathogens in the causation of diarrheal disease in adults. Traditional emphasis on biochemical characteristics or somatic serotypes has caused microbiologists to overlook perhaps more important criteria: bacteria-induced, altered physiology in the host and reproduction of these events in animal models.

\footnotetext{
${ }^{1}$ Abbreviations used in this paper: AUD, acute undifferentiated diarrhea; EEC, enteropathogenic Escherichia coli; TCBS, thiosulfate-citrate-bile salt-sucrose.
} 


\section{METHODS}

During the year November 1967 to November 1968, 164 adult males with acute diarrhea were studied at the Infectious Diseases Hospital, Calcutta. Bacteriologic diagnosis was established in 112 cases and included $V$. cholerae biotype eltor (94 cases), noncholera vibrios (16 cases), and Shigella flexneri (two cases). The remaining patients were considered to have acute undifferentiated diarrhea.

17 of the 52 AUD cases were selected for intubation studies on admission and comprise the material for this report. Informed consent was obtained in advance from all patients. Selection for intubation was based on choosing the more severely ill cases admitted on any particular day. Patients were intubated before the bacteriological diagnosis was known since the laboratory usually required 1 to 3 days to identify enteric pathogens. Patients with diarrhea, not selected for the intubation protocol, had bacteriological studies made of the fecal effluent as outlined below.

After an initial period of rehydration (generally 1 to 3 $\mathrm{hr}$ ), a triple-lumen, polyvinyl tube was passed perorally under fluoroscopic control. All samples were obtained while the patients were fasting or at least $2 \mathrm{hr}$ after eating. During convalescence, generally 7 to 10 days after admission, intubation for bacteriology and perfusion was repeated. The details of sampling in the small bowel and collection of fecal specimens have been outlined in previous publications $(6,7,10,11)$.

Quantitative and qualitative studies of intestinal samples were performed in eight media under aerobic and anaerobic conditions (6). To search for enteric pathogens, additional selective media were employed: SS agar, bismuth sulfate agar, MacConkey agar, bile salt agar and TCBS agar (thiosulfate-citrate-bile salt-sucrose, Difco Laboratories, Inc., Detroit, Mich.). All specimens were enriched in selenite broth and alkaline peptone water ( $\mathrm{pH}$ 9.2) and replated on SS agar and TCBS agar respectively.

With the aid of a hand lens and a dissecting microscope, multiple colonies were picked off MacConkey agar in an attempt to identify as many species and biotypes as possible. Suspicious colonies from the other selective media were also examined by biochemical and serological methods. In addition, 5-10 colonies were subcultured from the highest dilution MacConkey plates and preserved for serotyping. These procedures were carried out on all small bowel and fecal specimens.

Biotyping by biochemical and physiological characteristics was performed according to Edwards and Ewing (12). Specific antisera were available for salmonellae, shigellae, $V$. cholerae, and enteropathogenic $E$. coli. Oxidase-positive bacteria were classified according to Eddy and Carpenter (13). E. coli serotyping was accomplished at the National Communicable Disease Center, Atlanta, Georgia, under the supervision of Dr. W. Martin and Miss Betty Davis.

Viral isolation was attempted in 14 of the 17 patients selected for intubation. Small bowel samples collected during the acute illness were inoculated in Hep-2 and monkey kidney tissue cultures and in suckling mice. (This work was performed by Dr. William Hillis).

Rabbit intestinal loop test. Strains of $E$. coli were studied for enteropathogenicity in the rabbit model originally described by De and Chatterjee (14) and revised by Burrows and Musteikis (15). The test strain was grown in syncase broth (16) for $18 \mathrm{hr}$ in a shaking water bath at $37^{\circ} \mathrm{C}$. Following centrifugation, the supernatant was filtered through a $0.45 \mu$ Millipore filter (Millipore Corp., Bedford, Mass.).
Leunberg rabbits (Scientific Small Animal Laboratories), weighing approximately $2 \mathrm{~kg}$ with an average age of 10 wk, were used throughout these experiments. These are the same animals obtained by Dr. W. Burrows and our techniques were standardized by cooperation and advice from his laboratory. After $48 \mathrm{hr}$ of fasting, the animals were anesthetized and six intestinal loops of $10-12 \mathrm{~cm}$ length were constructed starting at the terminal ileum and proceeding proximally. Four of these loops were injected with $2 \mathrm{ml}$ of sterile broth filtrate from different test strains; the remaining two loops were used for a negative control (uninoculated broth) and a positive control ("whole cell lysate" from $V$. cholerae 569B supplied by Dr. Burrows). The order of loop inoculation was randomized among the six test materials and changed in each animal. The animals were sacrificed at $18 \mathrm{hr}$ and the loops were examined for dilatation and fluid accumulation. A positive loop had a volume: length ratio of greater than 1.0.

Approximately five strains of each $E$. coli serotype were examined in this rabbit model. Sterile broth filtrates of these strains were prepared on two separate occasions; each filtrate was injected into four animals. Hence, the five strains of a particular serotype were each tested in eight intestinal loops in as' many animals.

\section{RESULTS}

The 17 AUD cases with complete bacteriological studies of their small and large intestine could be divided into 2 groups.

TABLE I

Rank Order of Prevalence of Microorganisms in Stool of Patients with Diarrhea (Mean $\log _{10} / \mathrm{ml}$ or $\mathrm{gm}$ )

\begin{tabular}{|c|c|c|c|c|}
\hline \multirow{2}{*}{$\begin{array}{l}\text { Rank } \\
\text { order }\end{array}$} & \multicolumn{2}{|c|}{ E. coli flora (8 patients) } & \multicolumn{2}{|c|}{ Mixed flora (9 patients) } \\
\hline & Acute & Convalescent & Acute & Convalescent \\
\hline 1 & $\begin{array}{l}\text { E. coli } \\
(8.6)\end{array}$ & $\begin{array}{c}\text { Bacteroides* } \\
\qquad(8.6)\end{array}$ & $\begin{array}{l}\text { Coliforms } \\
\text { (mixed) } \\
(7.4)\end{array}$ & $\begin{array}{c}\text { Bacteroides* } \\
\text { (8.7) }\end{array}$ \\
\hline 2 & $\begin{array}{c}\text { Bacteroides } \\
\quad(5.8)\end{array}$ & $\begin{array}{l}\text { Coliforms* } \\
(7.6)\end{array}$ & $\begin{array}{l}\text { Streptococci } \\
\quad(6.5)\end{array}$ & $\begin{array}{l}\text { Streptococci* } \\
\quad(7.8)\end{array}$ \\
\hline 3 & $\begin{array}{l}\text { Streptococci } \\
\quad(5.3)\end{array}$ & $\begin{array}{l}\text { Streptococci* } \\
\quad(7.5)\end{array}$ & $\begin{array}{c}\text { Bacteroides } \\
\quad(5.8)\end{array}$ & $\begin{array}{l}\text { Coliformst } \\
\quad(7.2)\end{array}$ \\
\hline 4 & $\begin{array}{c}\text { Anaerobic } \\
\text { lactobacilli } \\
\quad(4.0)\end{array}$ & $\begin{array}{l}\text { Anaerobic } \\
\text { lactobacilli* } \\
\quad(7.4)\end{array}$ & $\begin{array}{c}\text { Clostridia } \\
\text { (3.9) }\end{array}$ & $\begin{array}{l}\text { Anaerobic } \\
\text { lactobacilli* } \\
\quad(7.1)\end{array}$ \\
\hline 5 & $\begin{array}{c}\text { Aerobic } \\
\text { lactobacilli } \\
(3.8)\end{array}$ & $\begin{array}{c}\text { Aerobic } \\
\text { lactobacilli* } \\
(5.2)\end{array}$ & $\begin{array}{c}\text { Anaerobic } \\
\text { lactobacilli } \\
\quad(3.0)\end{array}$ & $\begin{array}{l}\text { Aerobic } \\
\text { lactobacilli* } \\
\quad(5.9)\end{array}$ \\
\hline 6 & $\begin{array}{l}\text { Fungi } \\
(2.1)\end{array}$ & $\begin{array}{l}\text { Clostridia* } \\
\text { (4.0) }\end{array}$ & $\begin{array}{c}\text { Aerobic } \\
\text { lactobacilli } \\
(2.2)\end{array}$ & $\begin{array}{l}\text { Clostridia* } \\
\text { (5.1) }\end{array}$ \\
\hline 7 & $\begin{array}{c}\text { Staphylococci } \\
(2.0)\end{array}$ & $\begin{array}{l}\text { Fungi* } \\
(3.0)\end{array}$ & $\begin{array}{c}\text { Staphylococci } \\
(1.8)\end{array}$ & $\begin{array}{l}\text { Fungif } \\
(2.3)\end{array}$ \\
\hline 8 & $\begin{array}{c}\text { Clostridia } \\
\quad(1.0)\end{array}$ & $\begin{array}{c}\text { Staphylococcif } \\
\text { (1.7) }\end{array}$ & $\begin{array}{l}\text { Fungi } \\
(1.6)\end{array}$ & $\begin{array}{c}\text { Staphylococcif } \\
(2.2)\end{array}$ \\
\hline
\end{tabular}

* Differences between acute and convalescent values are significant $(P<0.02)$.

$\ddagger$ Differences between acute and convalescent values are not significant $(P>0.05)$ 


\section{E. coli group (eight patients)}

Acute studies. The microflora of the intestinal tract was composed largely of Escherichia coli. The concentration of $E$. coli in the fecal effluent was generally 1-3 logs higher than other aerobic or anaerobic bacteria (Table I). In seven of the eight patients, these organisms were also found in the upper small bowel. The most proximal site was the stomach in five cases, duo- denum in one case, and midjejunum in one case (Table II).

Serotyping of E. coli isolates showed that five of the eight cases had a single serotype in the small and large bowel (Table II). Patient 931 had two serotypes (078 and 0126) in approximately equal concentrations. Two patients had different serotypes in the small bowel and stool. In patient 79, nine isolates from the fecal effluent were $06: \mathrm{H} 16$, but multiple colonies cultured

TABLE II

Concentrations and Serotypes of E. coli in the Gastrointestinal Tract of Eight Patients with Diarrhea and a Fredominant E. coli Flora

\begin{tabular}{|c|c|c|c|c|c|}
\hline \multirow[b]{3}{*}{ Patient } & \multicolumn{5}{|c|}{ Concentrations and serotypes of $E$. coli } \\
\hline & \multicolumn{3}{|c|}{ Stomach and Small Bowel } & \multicolumn{2}{|r|}{ Stool } \\
\hline & Location & E. coli $/ \mathrm{ml}$ & Serotypes & E. coli/ml & Serotypes \\
\hline \multirow{3}{*}{924} & Stomach & $10^{5}$ & $015: \mathrm{H} 11$ & $10^{7}$ & $015: \mathrm{H} 11$ \\
\hline & Duodenum & $10^{5}$ & $015: \mathrm{H} 11$ & & \\
\hline & Mid jejunum & $10^{4}$ & $015: \mathrm{H} 11$ & & \\
\hline \multirow[t]{3}{*}{928} & Mid jejunum & $10^{3}$ & 078:H12 & $10^{\circ}$ & 078:H12 \\
\hline & Upper ileum & $10^{6}$ & 078:H12 & & \\
\hline & Terminal ileum & $10^{8}$ & 078:H12 & & \\
\hline \multirow[t]{4}{*}{931} & Stomach & $10^{6}$ & $\begin{array}{l}078: \mathrm{H} 12^{*} \\
0126: \mathrm{H} 12: \mathrm{K} \text { ?* }\end{array}$ & $10^{8}$ & $\begin{array}{l}078: \mathrm{H} 12^{*} \\
0126: \mathrm{H} 12: \mathrm{K} \text { ?* }\end{array}$ \\
\hline & Duodenum ` & $10^{5}$ & $\begin{array}{l}078: \mathrm{H} 12^{*} \\
0126: \mathrm{H} 12: \mathrm{K} \text { ? }^{*}\end{array}$ & & \\
\hline & Upper jejunum & $10^{6}$ & $\begin{array}{l}078: \mathrm{H} 12^{*} \\
0126 \cdot \mathrm{H} 12 \cdot \mathrm{K} \text { ?* }\end{array}$ & & \\
\hline & & & 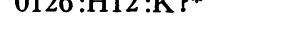 & & \\
\hline \multirow[t]{5}{*}{936} & Stomach & $10^{6}$ & $025: \mathrm{H} 42$ & $10^{8}$ & $025: \mathrm{H} 42$ \\
\hline & Duodenum & $10^{7}$ & $025: \mathrm{H} 42$ & & \\
\hline & & & $026: \mathrm{H} 32 \ddagger$ & & \\
\hline & & & 0115 :H42‡ & & \\
\hline & Mid jejunum & $10^{6}$ & $025: \mathrm{H} 42$ & & \\
\hline \multirow[t]{2}{*}{969} & Stomach & $10^{2}$ & $015: \mathrm{H} 11$ & $10^{\circ}$ & $015: \mathrm{H} 11$ \\
\hline & Lower jejunum & $10^{3}$ & $015: \mathrm{H} 11$ & & \\
\hline \multirow[t]{5}{*}{79} & Stomach & $10^{2}$ & $0115: \mathrm{H} 27$ & $10^{8}$ & $06: \mathrm{H} 16$ \\
\hline & Duodenum & $10^{5}$ & $0115: \mathrm{H} 27$ & & \\
\hline & Upper jejunum & $10^{6}$ & $0115: \mathrm{H} 27$ & & \\
\hline & Mid jejunum & $10^{7}$ & $0115: \mathrm{H} 27$ & & \\
\hline & Lower jejunum & $10^{6}$ & $0115: \mathrm{H} 27$ & & \\
\hline \multirow[t]{2}{*}{89} & Duodenum & $10^{3}$ & $0126: H 12: B 16$ & $10^{\circ}$ & 0126 :H12 :B16 \\
\hline & Mid jejunum & $10^{6}$ & 0126 :H12 :B16 & & \\
\hline 966 & Mid ileum $\S$ & $10^{8}$ & $\begin{array}{l}012 \text { :untypable } \mathrm{H} \\
\text { untypable } 0: \mathrm{H} 27 \ddagger\end{array}$ & $10^{8}$ & Untypable $0: \mathrm{H} 27$ \\
\hline
\end{tabular}

* Two serotypes present in approximately the same concentration.

$\ddagger$ One colony.

$\$$ No $E$. coli in the upper small bowel. 


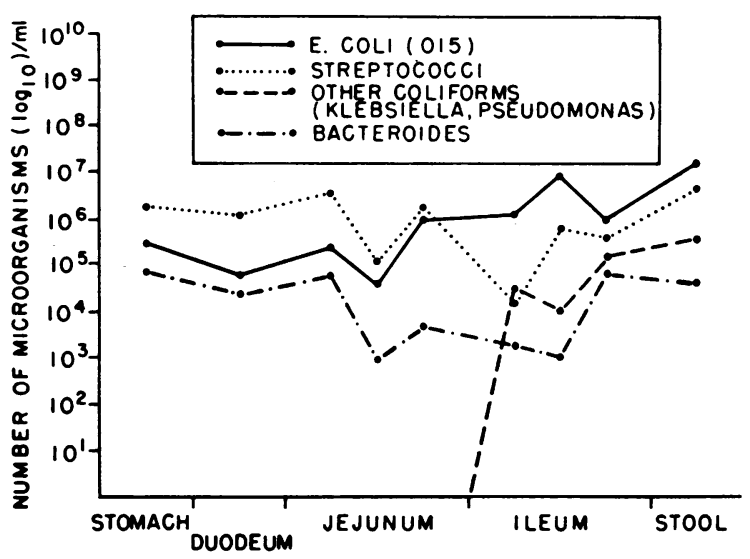

Figure 1 Intestinal microflora in a patient (No. 924) with AUD.

from the small bowel were $0115: \mathrm{H} 27$. Similarly, six colonies from stool of patient 966 were untypable $0: \mathrm{H} 27$; however, of six colonies from the midileum, five were 012 :untypable $H$ and only one was untypable $0: \mathrm{H} 27$.

Type 0126 containing $\mathrm{K}$ antigen were isolated from patients 931 and 89 . The $\mathrm{K}$ antigen from the latter was $\mathrm{B} 16$, indicating a recognized enteropathogenic serotype (0126:B16). The $\mathrm{K}$ antigen from patient 931 was not B16, but it could not be further identified.

Components of the normal microflora were also present during the acute episode. In patient 924, (Fig. 1), Streptococci and Bacteroides were recovered from all areas of the bowel; in addition, Klebsiella and Pseudomonas were found in the ileum and stool. (The Bacteroides strains in the small bowel failed to grow in $10 \%$ bile suggesting that they originated in the oral cavity [17]).

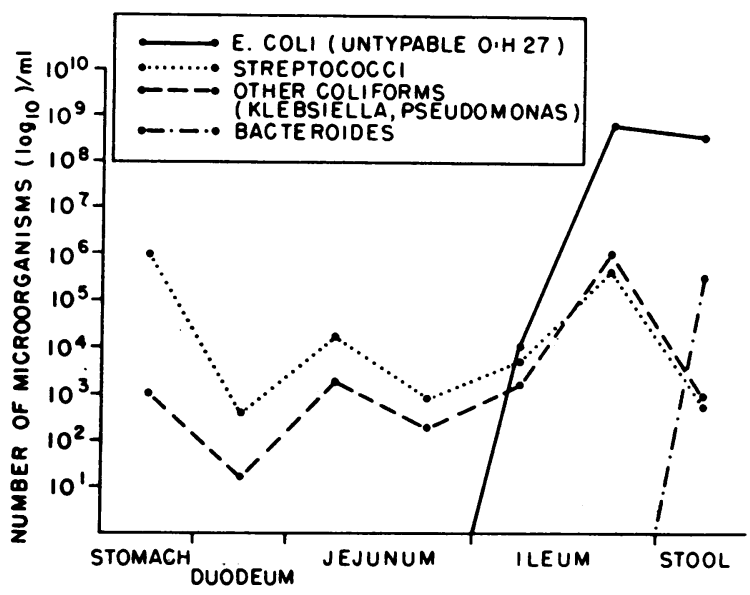

FIGURE 2 Intestinal microflora in a patient (No. 966) with AUD. Coliforms were not present in the jejunum.
E. coli were not found in the upper small bowel of patient 966 , but rather large concentrations $\left(10^{8} / \mathrm{ml}\right)$ were present in the ileum (Fig. 2). Smaller numbers of Streptococci, Klebsiella, and Pseudomonas were isolated from the small bowel, but Bacteroides were only in the feces.

Convalescent studies. When restudied, 7-10 days after admission, three patients had $E$. coli in the upper small bowel (Fig. 3). The serotypes changed in two (Nos. 924 and 931) and remained the same in the third (No. 79) (Table III). In the last patient, the original serotype (0115) isolated from the small bowel persisted during convalescence and also colonized the large bowel; however, the serotype (06) formerly present in the feces was eliminated. Patient 924 was restudied 2 months after the acute episode and coliforms were still present in the jejunum (Fig. 3). No coliforms were found in the jejunum of the other four patients who previously had organisms in this region.

Fecal microbial populations also changed in the convalescent studies (Table I). For example, coliforms were significantly reduced. $E$. coli remained the most prevalent species, but there were two to four different biotypes represented. Furthermore, serotypes found in the acute period were not present in the follow-up specimens.

The most striking change in the convalescent fecal specimens was the increased concentration of anaerobic bacteria. Viable counts of Bacteroides, anaerobic lactobacilli, and clostridia rose in all patients by $1-4$ logs.

\section{Mixed coliform group (nine patients)}

Acute studies. The fecal microflora contained several serotypes and biotypes of enteric bacteria, and it was

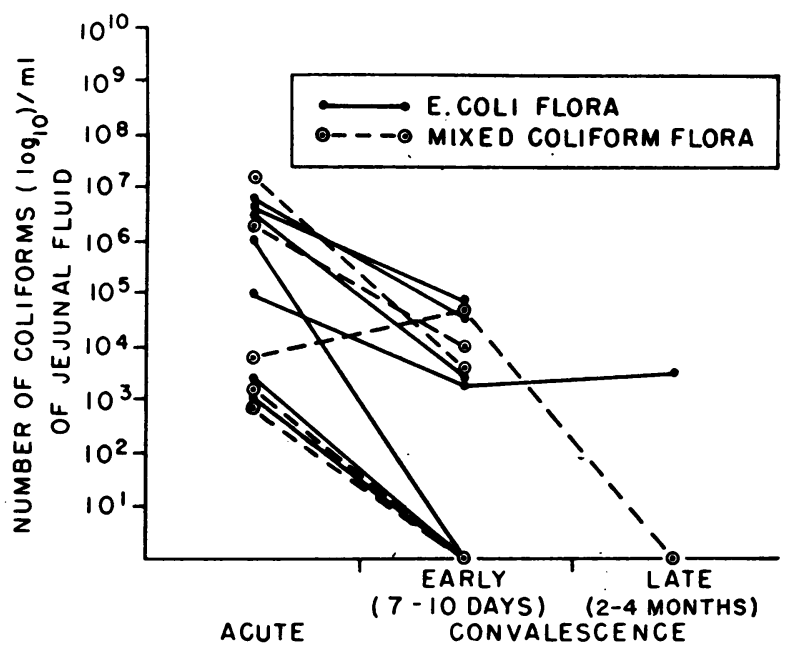

Figure 3 Concentrations of coliforms in jejunal fluid of patients with AUD. Studies were performed in the acute period and in the early and late convalescent periods. 
difficult to select a predominant strain (Table IV). E. coli was the most prevalent species in five of the nine patients, but several biotypes were isolated as well as other Gram-negative bacteria. The small bowel also contained two to three different species, and a distinctive pattern was not obvious.

Viable coliform counts were not increased in the acute phase (Table I). The change in rank order of prevalence in the follow-up studies was due to increased numbers $(1-4 \operatorname{logs})$ of anaerobic and microaerophilic bacteria.

E. coli isolated from the small bowel or stool during the acute stage were screened with the enteropathogenic $E$. coli typing sera. ${ }^{2}$ There were no positive agglutinations among the 25 strains from these nine patients.

Convalescent studies. Small numbers of coliforms (E. coli, Klebsiella and Enterobacter) persisted in the jejunum of three of five patients during convalescence (Fig. 3). As in the E. coli group, patients with initial coliform concentrations of less than $3.5 \mathrm{log} / \mathrm{ml}$ in the jejunum appeared to clear these organisms after the acute diarrheal episode. One patient (No. 912) was available for restudy 4 months later and coliforms were no longer found in the upper small bowel.

Rabbit loop studies. Broth filtrates obtained from $E$. coli strains in the five patients who had a single serotype in their small bowel and feces produced positive reactions in the intestinal loop (Table V). Patient 931 had two serotypes (078 and 0126) in the GI tract in approximately equal concentrations; broth filtrates of both strains were reactive in the rabbit intestinal loop.

In patient 966 , two serotypes were isolated from the mid ileum, 012 :untypable $\mathrm{H}\left(10^{8} / \mathrm{ml}\right)$ and untypable $0: \mathrm{H} 27\left(10^{7} / \mathrm{ml}\right)$; in the stool, however, only the untypable $0: \mathrm{H} 27$ could be identified. The latter serotype from either the small bowel or stool was found to be toxigenic whereas the 012 :untypable $\mathrm{H}$ was unreactive in the rabbit loop. Similarly, patient 79 had different serotypes in the small bowel and feces. The strains from the feces $(06: \mathrm{H} 16)$ were toxigenic but the small bowel isolates $(0115: \mathrm{H} 27)$ were unreactive. The toxigenic strain $(06: \mathrm{H} 16)$ may have been cleared from the small bowel at the time of the initial study. It was replaced by $0115: \mathrm{H} 27$ which persisted in convalescence and by that time had colonized the entire GI tract.

E. coli strains which were obtained during convalescence from the small bowel and feces were studied in four patients, (Nos. 924, 931, 966, and 79). Broth filtrates of convalescent strains were uniformly negative in the rabbit intestinal loop.

Viral studies. No enteroviruses were isolated from

${ }^{2} 026$ :B6, 055 :B5, 0111 :B4, 0127 :B8, 086 :B7, 0119:B14, $0124: B 17,0125: B 15,0126: B 16,0128: B 12$. (Difco Laboratories, Inc., Detroit, Mich.).
TABLE III

Coliforms in the Jejunum of Patients Convalescing from Diarrhea Who Had a Predominant E. coli Flora during the Acute Episode*

\begin{tabular}{|c|c|c|}
\hline \multirow[b]{2}{*}{ Patient } & \multicolumn{2}{|c|}{ Microorganisms in jejunal fluid } \\
\hline & Biotypes & E. coli serotypes \\
\hline 924 & $\begin{array}{l}\text { E. coli (3 types) } \\
\text { Alcaligenes faecalis }\end{array}$ & $\begin{array}{l}\text { Changed to untypable } 0 \\
\text { (Rough:H19) } \ddagger\end{array}$ \\
\hline 931 & E. coli (3 types) & Changed-not typed $\S$ \\
\hline 966 & Klebsiella species & -------- \\
\hline 79 & E. coli & $\begin{array}{l}0115: \mathrm{H} 27 \mp-\text { Same as } \\
\text { previous small bowel } \\
\text { strains; previous stool } \\
\text { strains (06:H16) } \\
\text { were not found }\end{array}$ \\
\hline
\end{tabular}

* Patients 928, 936, 969, and 89 had no coliforms in the jejunum when studied during convalescence.

$\ddagger$ Same serotype present in stool.

$\S$ These strains did not agglutinate with 015 serum (previous serotype); however, definitive typing was not done.

small bowel specimens of 14 patients either by direct tissue culture inoculation or by two subsequent blind passages. There was a single isolation of a reovirustype 1 from patient 85 .

\section{DISCUSSION}

Certain serotypes of Escherichia coli are known to cause acute gastroenteritis in humans. Such strains, designated enteropathogenic $E$. coli (EEC), have generally been associated with outbreaks of diarrhea in infant nurseries $(18,19)$. The disease can be reproduced by feeding EEC to healthy adult volunteers $(20,21)$.

While the search for enteropathogenic serotypes has proven fruitful in infantile diarrhea, sporadic cases of gastroenteritis in children or in adults are not usually associated with these type-specific strains. This was our experience in Calcutta, since only 1 of 17 cases of AUD had a recognized enteropathogenic serotype (0126: B16).

The location of coliform organisms within the GI tract is altered during acute diarrhea. In healthy individuals, the stomach, duodenum, and jejunum are free of coliform organisms $(10,11)$. Colonization of this area occurs in AUD and in diarrhea caused by Vibrio cholerae (7) and EEC (22). Coliforms are generally cleared from the upper small bowel within 7-10 days of the acute episode but some patients may have persistence of this abnormality for several weeks (7).

The rabbit intestinal loop model was originally designed to study the toxigenicity of cholera vibrios (14). Taylor et al. subsequently showed that pathogenic 
strains of $E$. coli from cases of infantile diarrhea also caused dilatation of the rabbit intestinal loop $(23,24)$. However, the same serotypes of $E$. coli isolated from the feces of healthy carriers or from extraintestinal sources such as the urinary tract were unreactive in this model.

The rabbit is not the only animal susceptible to the enteropathogenic effects of $E$. coli. In our laboratory we have observed net secretion and fluid accumulation in the GI tract of dogs receiving broth filtrates of $E$. coli isolated from our cases of AUD. Furthermore, in collaboration with Dr. Sam Formal of the Walter Reed Army Institute of Research, diarrhea has been produced in monkeys challenged with viable cultures of these strains.

There are other enteropathogenic serotypes of $E$. coli,

TABLE IV

Concentrations and Biotypes of Coliforms in the Gastrointestinal Tract of Nine Fatients with Diarrhea and a Mixed Coliform Flora

\begin{tabular}{|c|c|c|c|c|c|}
\hline \multirow[b]{3}{*}{ Patient } & \multicolumn{5}{|c|}{ Concentrations and biotypes of coliforms } \\
\hline & \multicolumn{3}{|c|}{ Stomach and Small Bowel } & \multicolumn{2}{|r|}{ Stool } \\
\hline & Location* & Organisms $/ \mathrm{ml}$ & Biotypes & Organisms/ml & Biotypes \\
\hline 912 & Upper jejunum & $\begin{array}{l}10^{5} \\
10^{3} \\
10^{2}\end{array}$ & $\begin{array}{l}\text { Klebsiella } \text { species } \\
\text { Pseudomonas species } \\
\text { Escherichia } \text { coli }\end{array}$ & $\begin{array}{l}10^{8} \\
10^{8} \\
10^{6} \\
10^{5} \\
10^{4}\end{array}$ & $\begin{array}{l}\text { Escherichia coli } \\
\text { Escherichia coli-A-D } \ddagger \\
\text { Pseudomonas species } \\
\text { Proteus morganii } \\
\text { Vibrio species (non-cholera) }\end{array}$ \\
\hline 916 & Upper ileum & $\begin{array}{l}10^{5} \\
10^{5}\end{array}$ & $\begin{array}{l}\text { Aeromonas formicans } \\
\text { Escherichia coli }\end{array}$ & $\begin{array}{l}10^{7} \\
10^{5}\end{array}$ & $\begin{array}{l}\text { Escherichia coli ( } 3 \text { serotypes) } \\
\text { Proteus morganii }\end{array}$ \\
\hline 927 & Lower jejunum & $\begin{array}{l}10^{3} \\
10^{2}\end{array}$ & $\begin{array}{l}\text { Enterobacter cloacae } \\
\text { Escherichia coli }\end{array}$ & $\begin{array}{l}10^{5} \\
10^{3}\end{array}$ & $\begin{array}{l}\text { Enterobacter cloacae } \\
\text { Escherichia coli ( } 2 \text { biotypes) }\end{array}$ \\
\hline 934 & Upper jejunum & $\begin{array}{l}10^{7} \\
10^{5} \\
10^{4}\end{array}$ & $\begin{array}{l}\text { Pseudomonas species } \\
\text { Klebsiella species } \\
\text { Escherichia coli }\end{array}$ & $10^{7}$ & Escherichia coli (3 biotypes) \\
\hline 941 & Terminal ileum & $\begin{array}{l}10^{5} \\
10^{4}\end{array}$ & $\begin{array}{l}\text { Escherichia coli } \\
\text { Klebsiella species }\end{array}$ & $\begin{array}{l}10^{6} \\
10^{6} \\
10^{5} \\
10^{5} \\
10^{2} \\
10^{2}\end{array}$ & $\begin{array}{l}\text { Escherichia coli } \\
\text { Escherichia coli-slf } \S \\
\text { Klebsiella } \text { species } \\
\text { Enterobacter cloacae } \\
\text { Pseudomonas species } \\
\text { Alcaligenes faecalis }\end{array}$ \\
\hline 945 & Mid ileum & $\begin{array}{l}10^{5} \\
10^{4} \\
10^{3}\end{array}$ & $\begin{array}{l}\text { Enterobacter cloacae } \\
\text { Klebsiella } \text { species } \\
\text { Pseudomonas } \text { species }\end{array}$ & $\begin{array}{l}10^{7} \\
10^{6} \\
10^{6} \\
10^{4}\end{array}$ & $\begin{array}{l}\text { Escherichia coli (2 biotypes) } \\
\text { Klebsiella species } \\
\text { Enterobacter cloacae } \\
\text { Alcaligenes faecalis }\end{array}$ \\
\hline 85 & Stomach & $\begin{array}{l}10^{5} \\
10^{5} \\
10^{5}\end{array}$ & $\begin{array}{l}\text { Escherichia coli } \\
\text { Klebsiella species } \\
\text { Aeromonas formicans }\end{array}$ & $\begin{array}{l}10^{7} \\
10^{7} \\
10^{7}\end{array}$ & $\begin{array}{l}\text { Escherichia coli } \\
\text { Klebsiella species } \\
\text { Aeromonas formicans }\end{array}$ \\
\hline 86 & Upper ileum & $\begin{array}{l}10^{7} \\
10^{6}\end{array}$ & $\begin{array}{l}\text { Escherichia coli } \\
\text { Alcaligenes faecalis }\end{array}$ & $\begin{array}{l}10^{7} \\
10^{7} \\
10^{7} \\
10^{6}\end{array}$ & $\begin{array}{l}\text { Escherichia coli } \\
\text { Escherichia coli-slf\& } \\
\text { Klebsiella species } \\
\text { Plesiomonas shigelloides }\end{array}$ \\
\hline 914 & Upper jejunum & $\begin{array}{l}10^{3} \\
10^{2}\end{array}$ & $\begin{array}{l}\text { Escherichia coli } \\
\text { Klebsiella species }\end{array}$ & $\begin{array}{l}10^{7} \\
10^{6} \\
10^{6} \\
10^{5}\end{array}$ & $\begin{array}{l}\text { Aeromonas formicans } \\
\text { Escherichia coli } \\
\text { Vibrio species (non-cholera) } \\
\text { Klebsiella species }\end{array}$ \\
\hline
\end{tabular}

* Most proximal site of positive culture.

$\ddagger$ Alkalescens-Dispar Group (12).

$\S$ slf-slow lactose fermenter. 
different from the human strains, associated with diarrhea in hogs and calves. Extensive studies with the animal strains have defined a toxic material which causes fluid accumulation in the isolated intestinal loop model (25-27). Our preliminary experiments show that this material is similar to the enterotoxin from strains of $E$. coli isolated in human cases of diarrhea. ${ }^{3}$

The bacteriological and physiological techniques used in the present study of AUD have been previously applied to acute cholera $(6-8)$. Several points of similarity can be seen between cholera and AUD associated with a predominant E. coli flora: (a) In both situations, the entire gastrointestinal tract may be heavily colonized by a specific pathogenic microorganism. (b) The production of diarrheal fluid is apparently due to net secretion in the small bowel at the site of bacterial colonization (9). However, mucosal architecture remains intact and there is no tissue penetration by vibrios (28) or coliforms (9). (c) Filterable, toxic material can be obtained from in vitro cultivation of the microorganism. Instillation of this product in an appropriate animal reproduces the pathophysiological events.

There are, however, important differences between $E$. coli diarrhea and acute cholera. The most obvious is the reduced morbidity of $E$. coli gastroenteritis as reflected by smaller volume of diarrheal fluid and shorter duration of symptoms (9). This may be related to a more rapid clearance of toxigenic $E$. coli from the small bowel; in some patients the toxigenic strain was apparently cleared or greatly reduced in the small bowel within the time required for intubation, i.e., $24-36 \mathrm{hr}$ after onset of symptoms. By contrast, similar studies in cholera patients have shown that vibrios were not cleared from the small bowel until 4-8 days after admission (7).

The patients with a mixed coliform flora still represent a diagnostic enigma. Although alterations in coliform biotypes have been observed in a variety of naturally occurring and experimental diarrheal diseases $(29-34)$, it is still possible that certain microorganisms from the feces of our patients with a mixed flora might be pathogenic. For example, the experiments of Koya, Kosakai, and Fukasawa (35) with implantation of EEC in healthy volunteers showed that subjects who developed only mild diarrhea had a mixed intestinal microflora consisting of the pathogenic $E$. coli as well as other elements of the coliform flora. Those with severe diarrhea had a flora predominantly of the implanted EEC strain. Since the patients with a "mixed flora" in our series had relatively mild disease, pathogenic bacteria may be included among the several strains which were

\footnotetext{
${ }^{3}$ Sack, R. B., S. Gorbach, J. G. Banwell, B. Jacobs, and B. D. Chatterjee. 1970. Enterotoxigenic Escherichia coli isolated from patients with severe cholera-like disease. J. Infec. Dis. In press.
}

TABLE V

The Effect of Broth Filtrates of E. coli* on the Rabbit Intestinal Loop Model.

\begin{tabular}{|c|c|c|c|c|}
\hline \multirow[b]{2}{*}{ Patient } & \multicolumn{2}{|l|}{ Acute period } & \multicolumn{2}{|c|}{ Convalescent period } \\
\hline & E. coli strain & $\begin{array}{l}\text { Rabbit } \\
\text { loop } \\
\text { test }\end{array}$ & E. coli strain & $\begin{array}{c}\text { Rabbit } \\
\text { loop } \\
\text { test }\end{array}$ \\
\hline 924 & $015: \mathrm{H} 11$ & + & $? \ddagger$ & 0 \\
\hline 931 & $\begin{array}{c}078: H 12 \\
0126: H 12: K ?\end{array}$ & $\begin{array}{l}+ \\
+\end{array}$ & $? \ddagger$ & 0 \\
\hline 79 & $\begin{array}{r}06: \mathrm{H} 16 \\
0115: \mathrm{H} 27\end{array}$ & $\begin{array}{l}+ \\
0\end{array}$ & $0115: \mathrm{H} 27$ & 0 \\
\hline 966 & $\begin{array}{l}\text { Untypable } 0: \mathrm{H} 27 \\
012 \text { :untypable } \mathrm{H}\end{array}$ & $\begin{array}{l}+ \\
0\end{array}$ & $? \ddagger$ & 0 \\
\hline 928 & $078: \mathrm{H} 12$ & + & - & - \\
\hline 936 & $\begin{array}{r}025: \mathrm{H} 42 \\
026: \mathrm{H} 32 \\
0115: \mathrm{H} 42\end{array}$ & $\begin{array}{l}+ \\
0 \\
0\end{array}$ & - & - \\
\hline 969 & 015 :H11 & + & - & - \\
\hline 89 & 0126:H12:B16 & + & - & - \\
\hline
\end{tabular}

* $E$. coli strains were isolated from patients with diarrhea during the acute and convalescent periods.

$\ddagger$ Convalescent strains were different from the serotypes of the acute period; however, definitive typing was not done.

isolated. As noted above, clearance of pathogenic strains from the gastrointestinal tract occurs very rapidly, further compounding the difficulty in recognizing them in patients with mild disease. Experiments are currently underway to examine each of the strains from the mixed flora group in a variety of animal models.

In addition to the changes in coliform flora, marked reductions in fecal anaerobes were noted in diarrheal stool. We have previously reported similar findings in cholera "rice-water" stool (6), and in diarrheal stool produced experimentally in volunteers by fluid purgation or by feeding lactose to hypolactasic subjects (34). Moore, Cato, and Holdeman (36) have also found reduced concentrations of anaerobes in the feces of patients with gastroenteritis. These oxygen-sensitive strains require an environment of low oxidation-reduction potential and stasis; rapid passage through the colon, such as occurs in diarrhea, appears to adversely alter the natural physiochemical environment which supports the growth of these fastidious microorganisms.

The main emphasis of this study of AUD in Calcutta is to show that strains of $E$. coli may cause diarrheal disease without necessarily being recognized as "enteropathogenic" by standard serological and biochemical reactions. In order to produce clinical diarrhea, it would 
appear that three conditions must be fulfilled: The strain must be "toxigenic" as demonstrated in animal models; the concentration of these organisms must be of sufficient quantity $-10^{2} / \mathrm{ml}$ appears to be too few, but $10^{5}$ $10^{6} / \mathrm{ml}$ may be adequate; and the toxigenic strains of $E$. coli must be in contact with "sensitive" mucosa. This implies colonization of the upper small bowel since this area appears to be sensitive to $E$. coli toxin whereas the colon is probably unaffected (25).

Rowe, Taylor, and Bettelheim (37) have suggested that a previously unrecognized $E$. coli serotype, now designated $0148: \mathrm{K}$ ?: H28, was the cause of "Traveller's diarrhea" in English soldiers recently transferred to Aden. This is consistent with our findings in India that untypable $E$. coli or typable strains generally considered nonpathogenic may in fact be responsible for cases of acute undifferentiated diarrhea.

\section{ACKNOWLEDGMENTS}

These investigations were supported in part by the U. S. Public Health Service Research Grant H-26-6217-08 and by Grant 7-R22-A1-09851-01 from the National Institute of Allergy and Infectious Diseases.

\section{REFERENCES}

1. Gordon, J. E. 1964. Acute diarrheal disease. Amer. J. Med.Sci. 248: 345.

2. Sabin, A. B. 1963. Cause and control of fatal, infantile diarrheal diseases. Amer. J. Trop. Med. Hyg. 12: 556.

3. Guardiola-Rotger, A., E. F. deGonzalez, E. Kauder, A. Munoz, V. A. Lopez, D. E. Gadea, and M. J. Funkenbusch. 1964. Studies on diarrheal diseases: The multiplicity of infectious agents in the intestinal flora of Puerto Rican children with gastroenteritis. J. Pediat. 65: 81 .

4. Mata, L. J., C. Albertazzi, A. Negreros, and R. Fernandez. 1965. Prevalence of Shigella, Salmonella and enteropathogenic Escherichia coli in six Mayan villages. Amer. J. Pub. Health. Suppl. 55: 1396.

5. Cramblett, H. G., and C. M. F. Siewers. 1965. The etiology of gastroenteritis in infants and children, with emphasis on the occurrence of simultaneous mixed viralbacterial infections. Pediatrics. 35: 885 .

6. Gorbach, S. L., J. G. Banwell, B. Jacobs, B. D. Chatterjee, R. Mitra, K. L. Brigham, and K. N. Neogy. 1970. Intestinal microflora in Asiatic cholera. I. "Rice-water" stool. J. Infec. Dis. 121: 32.

7. Gorbach, S. L., J. G. Banwell, B. Jacobs. B. D. Chatterjee, R. Mitra, K. L. Brigham, and K. N. Neogy. 1970. Intestinal microflora in Asiatic cholera. II. The small bowel. J. Infec. Dis. 121: 38 .

8. Banwell, J. G., N. F. Pierce, R. C. Mitra, K. L. Brigham, G. J. Caranasos, R. I. Keimowitz, D. S. Fedson, J. Thomas, S. L. Gorbach, R. B. Sack, and A. Mondal. 1970. Intestinal fluid and electrolyte transport in human cholera. J. Clin. Invest. 49: 183.

9. Banwell, J. G., S. L. Gorbach, R. C. Mitra, N. F. Pierce, and A. Mondal. 1971. Acute undifferentiated human diarrhea in the tropics. II. Alterations in intes- tinal fluid and electrolyte movements. J. Clin. Invest. 50: 890 .

10. Gorbach, S. L., A. G. Plaut, L. Nahas, L. Weinstein, G. Spanknebel, and R. Levitan. 1967. Studies of intestinal microflora. II. Microorganisms of the small intestine and their relations to oral and fecal flora. Gastroenterology. 53: 856 .

11. Gorbach, S. L., J. G. Banwell, R. Mitra, B. D. Chatterjee. B. Jacobs, and D. N. Guha Mazumder. 1969. Bacterial contamination of the upper small bowel in tropical sprue. Lancet. $1: 74$.

12. Edwards. P. R., and W. H. Ewing. 1962. Identification of Enterobacteriaceae. Burgess Publishing Co., Minneapolis, Minn. 2nd edition.

13. Eddy, B. P., and K. P. Carpenter. 1964. Further studies on Aeromonas. II. Taxonomy of Aeromonas and C 27 strains. J. Appl. Bacteriol. 27 : 96.

14. De, S. N., and D. N. Chatterjee. 1953. An experimental study of the mechanism of action of Vibrio cholerae on the intestinal mucous membrane. J. Pathol. Bacteriol. 66: 559.

15. Burrows, W., and G. M. Musteikis. 1966. Cholera infection and toxin in the rabbit ileal loop. J. Infec. Dis. 116: 183.

16. Finkelstein, R. A., P. Atthasampunna, M. Chulasamaya, and P. Charunmethee. 1966. Pathogenesis of experimental cholera: Biologic activities of purified Procholeragen A. J. Immunol. 96: 440.

17. Loesche, W. J., S. S. Socransky, and R. J. Gibbons. 1964. Bacteroides oralis, proposed new species isolated from the oral cavity of man. J. Bacteriol. 88: 1329.

18. Neter, E. 1959. Enteritis due to enteropathogenic Escherichia coli: Present-day status and unsolved problems. J. Pediat. $55: 223$.

19. Taylor. J. 1966. Host-parasite relations of Escherichia coli in man. J. Appl. Bacteriol. 29: 1.

20. Ferguson, W. W., and R. C. June. 1952. Experiments of feeding adult volunteers with Escherichia coli 111, B4, a coliform organism associated with infant diarrhea. Amer. J. Hyg. 55: 155.

21. June, R. C., W. W. Ferguson, and M. T. Worfel. 1953. Experiments in feeding adult volunteers with Escherichia coli $55, \mathrm{~B} 5$, a coliform organism associated with infant diarrhea. Amer. J. Hyg. 57: 222.

22. Thomson, S. 1955. The numbers of pathogenic bacilli in faeces in intestinal diseases. J. Hyg. 53: 217.

23. Taylor, J., M. P. Maltby, and J. M. Payne. 1958. Factors influencing the response of ligated rabbit-gut segments to injected Escherichia coli. J. Pathol. Bacteriol. 76: 491 .

24. Taylor, J., M. P. Wilkins, and J. M. Payne. 1961. Relation of rabbit gut reaction to enteropathogenic Escherichia coli. Brit. J. Exp. Pathol. 42: 43.

25. Smith, H. W., and S. Halls. 1967. Observations by the ligated intestinal segment and oral inoculation methods on Escherichia coli infections in pigs, calves, lambs and rabbits. J. Pathol. Bacteriol. 93: 499.

26. Kohler, E. M. 1968. Enterotoxic activity of filtrates of Escherichia coli in young pigs. Amer. J. Vet. Res. 29: 2263.

27. Gyles, C. L., and D. A. Barnum. 1969. A heat-labile enterotoxin from strains of Escherichia coli enteropathogenic for pigs. J. Infec. Dis. 120: 419.

28. Gangarosa, E. J., W. R. Beisel, C. Benyajati, H. Sprinz, and P. Piyaratn. 1960. The nature of the gastrointestinal lesion in Asiatic cholera and its relation to patho- 
genesis: A biopsy study. Amer. J. Trop. Med. Hyg. 9: 125.

29. Kean, B. H. 1963. The diarrhea of travelers to Mexico. Summary of five-year study. Ann. Intern. Med. 59: 605.

30. Albert, J. P., J. G. Ricosse, and J. J. Picq. 1968. Resultats d'une étude des enterobacteries de la flora intestinale chez les amibiens. International Congresses on Tropical Medicine and Malaria. 8th, Teheran. 1154.

31. Topley, W. W. C., and G. S. Wilson. 1936. The Principles of Bacteriology and Immunity. Edward Arnold (Publishers) Ltd., London. W. 1. 2nd edition. 1250.

32. Olarte, J., W. W. Ferguson, N. D. Henderson, and L. Torregrosa. 1961. Klebsiella strains isolated from diarrheal infants. Amer. J. Dis. Child. 101: 763.

33. Cohen, R., M. H. Kalser, I. Arteaga, E. Yawn, D. Frazier, C. A. Leite, D. G. Ahearn, and F. Roth. 1967.
Microbial intestinal flora in acute diarrheal disease. J. Amer. Med. Ass. 201: 835.

34. Gorbach, S. L., G. Neale, R. Levitan, and G. W. Hepner. 1970. Alterations in human intestinal microflora during experimental diarrhea. Gut. 11: 1 .

35. Koya, G., N. Kosakai, and Y. Fukasawa. 1954. Supplementary studies on the multiplication of Escherichia coli $0-111 \mathrm{~B} 4$ in the intestinal tract of adult volunteers and its relation to manifestation of coli enteritis. Jap. J. Med. Sci. Biol. 7: 655 .

36. Moore, W. E. C., E. P. Cato, and L. V. Holdeman. 1969. Anaerobic bacteria of the gastrointestinal flora and their occurrence in clinical infections. J. Infec. Dis. 119: 641 .

37. Rowe, B., J. Taylor, and K. A. Bettelheim. 1970. An investigation of travellers' diarrheoa. Lancet. 1: 1 . 